DOI: 10.14807/ijmp.v11i5.1292

\title{
THE RENTABILITY OF THE SECOND AND THIRD PRODUCTION CYCLE OF THE EUCALYPTUS (CORYMBIA ANGOPHORA) IN ALTO TIETÊ COMMUNITY
}

\author{
Ronaldo Damião de Paula \\ Instituto Federal de São Paulo, Campus Suzano, Brazil \\ E-mail: rdpdamiao@gmail.com
}

Sivanilza Teixeira Machado Instituto Federal de Educação, Ciência e Tecnologia de São Paulo, Campus Suzano, Brazil E-mail: sivateixeira@yahoo.com.br

Submission: 2/28/2020

Revision: $3 / 3 / 2020$

Accept:3/8/2020

\section{ABSTRACT}

Over the years, the paper and cellulose industry in Alto Tietê community kept the eucalypt production system in partners with local farmers. However, the costs of the integrated systems were very higher, and contribute to the industry adopted the new strategy like investment in production mechanization in areas plains and most far. This hit the local market with eucalyptus devaluation. Thus, this paper aims to analyze the strategy applied by local farmers to reduce eucalypt production costs. The case study was carried out in the Salesópolis community, São Paulo, as an exploratory research to comprehend the impact of paper and cellulose industry change made in the local community. The results showed that the total cost estimated to first production cycle was 1.8 most than the second cycle and the rentability in 6.5 years was de 1,92\% less than other cycles. The third production cycle showed downs in land rentability, almost $18.5 \%$ less than the second cycle and $16.5 \%$ less than the first cycle. Therefore, the eucalypt production in the Alto Tietê community already was a big business and income source to local farmers and with eucalypt market devaluation and the cost increase of production and operation, the farmers had opted by the maintenance of the third cycle of production even not being the most profitable.

Keywords: production cycle; eucalypt; rentability. 
DOI: 10.14807/ijmp.v11i5.1292

\section{INTRODUCTION}

Alto Tietê is known as a production area of silviculture, and it drove in the 70s by the paper, cellulose and fiber industries installed in the region. In 2017, the area destined to eucalyptus production was 27 thousand hectares, the largest producer being the municipality of Salesópolis (37\%), followed by Mogi das Cruzes (26\%), Biritiba Mirim and Guararema together have the same share of Salesópolis (INSTITUTO BRASILEIRO DE GEOGRAFIA E ESTATÍSTICA - IBGE, 2017a).

According to IBGE survey (2017a), the average amounts paid for production were R\$ $36.77 / \mathrm{m}^{3}$ for firewood, $\mathrm{R} \$ 31.00 / \mathrm{m}^{3}$ for paper and cellulose, and $\mathrm{R} \$ 48.26 / \mathrm{m}^{3}$ for other purposes. For instance, in the last thirteen years, Salesópolis showed a variation in prices paid per $\mathrm{m}^{3}$ to production of eucalyptus for paper and cellulose, and it is observed that the best year for producers in the region was in 2009, with an increase of approximately $85 \%$ in the eucalyptus price ( $\mathrm{R} \$ 89.55$ ) and, the worst year was in 2015 with a 43\% drop in price ( $\mathrm{R} \$$ 61.19) compared to 2016. However, this price has not changed since 2013, and in 2017, the variation of price was 11.5\% (IBGE, 2017b).

Considering a devaluation of the eucalyptus cubic meter in the Alto Tietê region that reaching producers, and they have been looking for other cultures and alternatives production systems. Over the years, there has been a drop in eucalyptus production, for instance, in 2005 Salesópolis had a production of 357,087 $\mathrm{m}^{3}$, and in 2017 this production represented 83,190m³ (IBGE, 2017b). The integrated production system was a motivation to start the agroforestry activities in the region. In this system, producers were integrated into the industry chain, and they received in advance, technical consultancy on production, being responsible for the production itself. The partnership contract between industry and producer has the advantage or discount of $95 \%$ of the production or reduces the risks of markets to the producer. Likewise, as the producer received in advance, it can apply production and at the same time plan future investments.

For many years, the paper and cellulose industry maintained the partnership system with local eucalyptus producers. However, the costs to maintain the integrated production system was very high. The advantages of the mechanization and automation of the field, the industry invested in the eucalyptus production and increasingly distant regions from industry plant. According to Leite et al. (2014), the mechanized cutting plan contributes to maximizing the overall return, as it reduces labor costs and harvest time. This change shifted investments 
DOI: 10.14807/ijmp.v11i5.1292

from the Alto Tietê industry to other regions and led to the demotivation of local eucalyptus producers. Besides, for producers who still produce in the Alto Tietê region, the industry has maintained the price for some years, it has not kept up with the evolution of the market, and with the increased costs of manufacturing, locomotion, and manufacturing of eucalyptus in the region of Alto Tietê has become unviable.

Thus, this paper aims to analyze the strategy used by producers to reduce the production of eucalyptus costs in the Alto Tietê region.

\section{LITERATURE REVIEW}

\subsection{Eucalyptus in Brazil}

In 2015, the national value of plant extraction and forestry totaled R $\$ 18.4$ billion, and the forests cooperated with 74.3\%, which represents R $\$ 13.7$ billion of the totals (IBGE, 2016). The vegetal extraction contributed with $25.7 \%$, which represents $\mathrm{R} \$ 4.7$ billion, and the financial participation of wood products in the removal of vegetables reached $\mathrm{R} \$ 3.2$ billion and non-wood products totaled R\$1.5 billion (IBGE, 2016).

According to IBGE, in 2015, Minas Gerais, has a larger area of eucalyptus plantation territory with almost 1,8 million hectares, followed by São Paulo and Mato Grosso do Sul with 952,884 and 921,404 hectares, respectively (HADDAD, 2016). Eucalyptus is a tree that shows a significant economic gain, because its development quickly and widely used for cellulose production, in the manufacture of wood, charcoal, and paper. Production costs are estimated at $\mathrm{R} \$ 7,944.38$ per hectare (between land implementation and maintenance). The value of the wood cubic meter for cellulose is around R\$ 46.00 in the region (FILHO, 2014).

Since 2016 the eucalyptus yields less R\$ 1,400.00 per hectare, the eucalyptus wood subway on the firewood production farm has an average value of R\$ 31.05 in the São Paulo state, the last months of which exist drops in its price (CEPEA, 2017). The Brazilian forestry industry is vertically integrated, and large quantities of forestry products, benefits from indirect and direct jobs, allowing social development (MORAES, 2010). In 2012, the gross value in the production of eucalyptus representing $\mathrm{R} \$ 56.3$ billion, increasing by $4.6 \%$ concerning the last year (ABRAF, 2013). In addition, some people argue that planting eucalyptus can prevent the cutting and killing of native species, for such purposes, as would be an appropriate option for degraded lands, promoting the economy where they are grown (VITTI; BRITO, 1999). 
DOI: 10.14807/ijmp.v11i5.1292

\subsection{Eucalyptus, Cellulose and Production Cycle}

Eucalyptus also has its name applied to that of Mirtaceae, namely to some tree species of the genera (Corymbiae Angophora) (TURRA, 2011). There are 700 species, approximately all of which originate in Australia, with only a small number of species characteristic of the neighboring territories of New Guinea and Indonesia, and the most northern, which is in the southern Philippines (MORAES, 2010).

According to Revista Agroanalysis (2014), and eucalyptus in a cut point must be 6 to 7 years old, this is the right age to produce cellulose. For energy uses coal with 3 years, wood for civil construction and a fence post for 3 to 4 years old fences. Develop one hectare, 10,000 square meters, with a $3 \times 2$ meter spacing between trees and 1,667 feet of eucalyptus, with an average of 300 cubic meters per hectare. With a wood at 30\% humidity, 1 ton of eucalyptus weighs approximately 430 to $570 \mathrm{~kg}$ and requiring about 2 months for drying (REVISTA AGROANALYSIS, 2014).

According to Nishiyama, Langan e Chanzy (2002), cellulose starts manufacturing with eucalyptus, the wood like pine, in the smallest portion of herbaceous plants with a large amount of cellulose in the stem, sugar cane, numerous grasses and reeds, which convert this pulp into celluloid (previously used in cinematographic films), cellophane, pumps, cellulose acetate, carboxymethylcellulose (lubricants and emulsifiers) and others. "Cellulose (C6H10O5) is a long-chain polymer composed of a single monomer (glucose) classified as a polysaccharide or carbohydrate” (KAKAZU; ARIMATÉIA; SHIVARD, 2013).

The paper is made with a cellulose pulp. To be made with raw material, it must be peeled and clean, after mechanically crushed (KLOCK; ANDRADE; HERNANDEZ, 2013). According to the authors yet, the powdered substance can undergo several treatments for the separation of lignin, a substance that makes cellulose fibers join and can be treated with caustic soda, calcium bisulfite (acidic process), sodium sulfide (Kraft process) (NISHIYAMA; LANGAN; CHANZY, 2002). Then, the product must be purified, cleaned, whitened, and boiled water is used to mix it. Depending on the type of plant, long filament or short fiber cellulose is obtained. This feature leaves the paper with a more absorbent or more resistant result, respectively (NISHIYAMA; LANGAN; CHANZY, 2002). 
ISSN: 2236-269X

DOI: 10.14807/ijmp.v11i5.1292

\section{METHODOLOGY}

\subsection{Caracterização do estudo de caso}

To analyze the strategies used by eucalyptus producers in the Alto Tietê region, a case study was carried out in a local community, in the municipality of Salesópolis, approximately 120 km from São Paulo city. The producers are part of the local Cooperative, made up of small and medium-sized eucalyptus producers, destined for the pulp and paper industry, sawmills, civil construction, and charcoal production (CAMAT, 2019). To understand the eucalyptus production process, we carried out an open and unstructured interview was conducted with a specialist in the forestry area of the Alto Tietê region with over 34 years of experience. The interview took place on-site during technical visits and observation of the planted eucalyptus area in Salesópolis, during May 2019.

\subsection{The eucalyptus production system}

Currently, the eucalyptus farm visited has produce for maintenance and protection of the land. For many years it participated in the system of partnership with the industry, and 95\% of its production being absorbed and at prices considered adequate.

In recent years, the partnership among industry and producers were deactivated and the producers needed to modify the production system. Thus, they adopted the production system in three cycles, to guarantee the maintenance of the land, Table 1.

Table 1: Steps of the eucalyptus production cycle

\begin{tabular}{|c|c|c|}
\hline & Steps & Description \\
\hline 1 & Soil analysis & Determine the demand and amount of soil fertilization \\
\hline 2 & Seedlings & Seed or clone option \\
\hline 3 & Tree (1st cycle) & Tree at the cutting age (1st cycle) \\
\hline 4 & Planting maintenance & $\begin{array}{l}\text { Perform planting maintenance after the 1st cut and leave the stump area of the } \\
\text { cut tree free from other plants }\end{array}$ \\
\hline 5 & Sprouting & Monitor the growth of tree stump sprouts cut in the 1st production cycle \\
\hline 6 & $\begin{array}{l}\text { Selection of eucalyptus } \\
\text { sprouts }\end{array}$ & $\begin{array}{l}\text { Select from the sprouts, observing the age and height. Recommends } 2 \text { to } 3 \\
\text { sprouts per trunk to obtain a better yield }\end{array}$ \\
\hline 7 & Compensation & $\begin{array}{l}\text { The yield of the wood in the } 2 \text { nd cycle is lower than the } 1 \text { st cycle, due to several } \\
\text { factors. Therefore, it is recommended to keep } 2 \text { to } 3 \text { sprouts per trunk to } \\
\text { compensate for the yields difference between production cycles }\end{array}$ \\
\hline 9 & Tree $\left(2^{\circ}\right.$ cycle $)$ & Tree at the cutting age (2nd cut) \\
\hline 10 & $3^{\circ}$ cycle & Repeats steps 4 to 9 to obtain the 3rd cut in eucalyptus production. \\
\hline
\end{tabular}


ISSN: 2236-269X

DOI: 10.14807/ijmp.v11i5.1292

Thus, the data collected on production costs, productivity, and market value for each production cycle were analyzed. To achieve the results presented, the following equations were used, Table 2.

Table 2: Description of the equations used in this work

\begin{tabular}{|c|c|c|c|}
\hline Description & Equation & Reference & \\
\hline Wooden log volume $\left(\mathrm{m}^{3}\right)$ & $W v=\pi r^{2} h$ & $\begin{aligned} \mathrm{Wv} & =\text { Wooden log volume } ; \pi=\text { pi value } ; \mathrm{r} \\
& =\text { radius of a cylinder; } \mathrm{h}=\text { height }\end{aligned}$ & $(1)$ \\
\hline Average cost per plant (R\$) & $C p=T C / N p$ & $\begin{array}{c}\mathrm{Cp}=\text { cost per plant; } \mathrm{TC}=\text { total cost } \mathrm{Np}= \\
\text { Number of plants }\end{array}$ & $(2)$ \\
\hline Eucalyptus productivity (m³) & $E p=W v \times N p$ & $\begin{array}{c}\text { Ep = eucalyptus productivity; Wv = } \\
\text { Wooden log volume; Np = Number of } \\
\text { plants }\end{array}$ & (3) \\
\hline Profit $(\mathrm{R} \$)$ & $P=R-T C$ & $\mathrm{P}=$ Profit $\mathrm{R}=$ Revenue TC $=$ Total cost & (4) \\
\hline Land profitability (\%) & $\begin{aligned} L p= & (P / C i) x \\
& 100\end{aligned}$ & $\begin{array}{l}\text { Lp = Land profitability; } \mathrm{P}=\text { Profit } ; \mathrm{Ci}= \\
\text { Capital Investment for Land Acquisitions }\end{array}$ & (5) \\
\hline Annual land profitability (\%) & $A l p=L p / y u$ & $\begin{array}{c}\text { Alp = Annual land profitability; } \mathrm{Lp}= \\
\text { Land profitability; yu = years of land use }\end{array}$ & (6) \\
\hline
\end{tabular}

\section{RESULTS AND DISCUSSION}

\subsection{Manually and mechanized eucalyptus production process}

The main difference between the manually and mechanized production process is in its planning and the decision making between maintaining production with the sprouting for the 2nd and 3rd cycle or restarting the 1st production cycle with new seedlings, Figure 1 and 2.

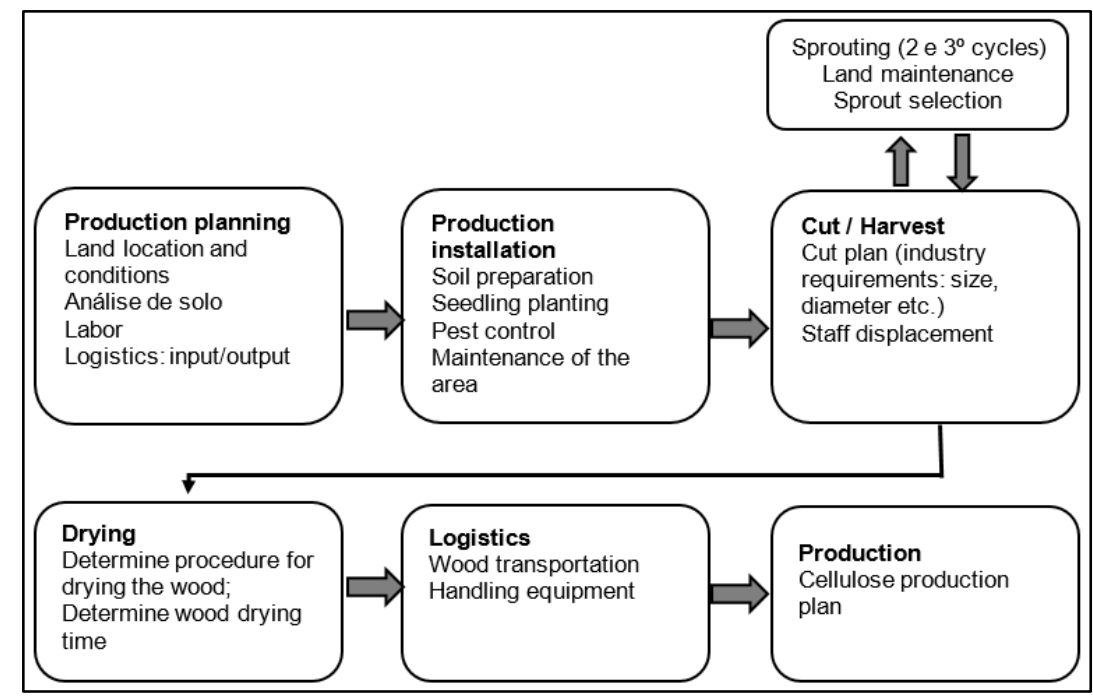

Figure 1: Description of the manually eucalyptus production process Source: Adapted from Almeida (2019) 
DOI: 10.14807/ijmp.v11i5.1292

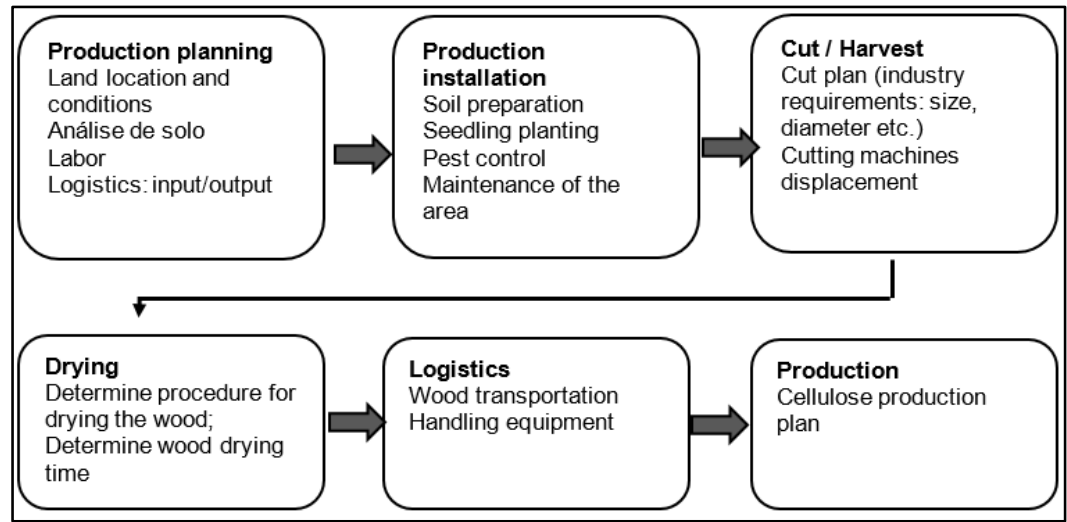

Figure 2: Description of the mechanized eucalyptus production process Source: Adapted from Almeida (2019)

Regardless of the type of production system chosen, the producer must carry out the production planning for later installation. At this stage, the producer must prepare the land for the first cut with fertilizers (nitrogen, phosphorus, and potassium). The amount of the nutrients depends on the conditions of the land or the land genetic improvement that occurs with the opening of a determined space for oxygen circulation. For the second and third cut, the producer must perform fertilization to maintain the land. In addition to carrying out the land genetic improvement, the producer must seek to clean the soil, removing tree stumps, debris, branches, among others. It is necessary to remove all barks from the wood, that is, the place must be clean for the next cut.

A plantation of eucalyptus seedlings should obey the cutting plan, with spacing between lines of $3 \times 2$ meter or $6 \mathrm{~m}^{2}$ per planted tree, this means that there are 1,667 seedlings planted per hectare (ALMEIDA, 2019). Seedlings take 6 to 7 years to reach the cutting age. The height of the trees can vary between 23 to 32 meters, and the average diameter accepted by the industry is 15 to $20 \mathrm{~cm}$, without bark. Eucalyptus trees can have several types of consumption, depending on their diameter, such as paper and cellulose, wood for charcoal, civil construction, etc. Generally, an average productivity of each tree is $0.18 \mathrm{~m}^{3}$, the volume of hardwood, for paper and cellulose.

The mechanized production process, after the first cut, the land is cleaned and the analysis of the land condition is verified again, to fertilization if it is necessary, as well as, the planting of new seedlings and the production process is restarted, always maintaining the first cut. The preference for using machines concerning to the gain in productivity and reduction in production costs, especially about the cost of cutting, loading, and transport (LEITE et al., 2014; MACHADO; GURGEL; GAMEIRO, 2015). The standardization of the wooden log cut in $6 \mathrm{~m}$, also optimizes transport costs, given the dimensions of the transport vehicle. 
DOI: 10.14807/ijmp.v11i5.1292

For the manually production process, after the first cut, a stump with a height from the ground up to $12 \mathrm{~cm}$ is recommended, and cleaning the area must take into account a good fertilization to avoid damage, as well as pests, and keep only eucalyptus stumps. Besides, fertilization is carried out to maintain the land and the selection of sprouts. The selection of stems concerning to discarded (cut) some sprouts, and maintain some defined sprouts, with a better quality possible and in a position to be able to develop freely, as eucalyptus needs space and ventilation for its growth. Generally, it recommends an average of 02 to 03 sprouts per stump, depending on its wooden quality. The objective is to achieve superior forest quality, one must observe and be rigorous in the choice of the remaining stems, "concerning the following aspects: vigorous development; better encompassing of the stems in the stump; stems located in the lower part of the stump, and as much space as possible between the stems” (ALMEIDA, 2019).

The decision making to not carry out the selection of sprouts provides competition for growth between the stems due to lack of space and soil nutrients, which will result in lowquality material for the market, so the wood produced does not reach the expected diameter for industry, becoming wood for firewood and civil construction. The producer must carry out the selection of sprouts when he has restrictions of heights of 6 to 7 meters. The selection of sprouts is a strategy to compensate for the failures of eucalyptus planting and seek the best yield as similar the productivity of the first production cycle.

The cutting of the stems must be done as low as possible, and this is a very delicate operation because any slip can the injury in remaining stems, impairing its development. Thus, the use of correct tools and position at the time of the 'hit' in stems that will be discarded are fundamental. In the cutting operation, the most used tools are a scythe and an ax, and since the scythe does not even good quality of service in stems cutting, it can cause enough damage to the remaining stems. Therefore, the scythe can be used in the land cleanings and ax can be used exclusively in the cutting of stems. The ax must have a profile, weight, and size that provide good performance and less physical wear to the farmer. Also important is the size and shape of the cable, if possible, avoid using wedges.

According to Almeida (2019), the manually cutting of wood logs is standardized at 2.2 $\mathrm{m}$, due to the ease of handling and movement by workers, and the wood log is peeled manually with machetes and axes. Larger wood logs become heavy for handling process. However, in the mechanized process, a harvester machine cuts the standard wood logs at $6 \mathrm{~m}$ in height, as well as it peels the wood log. "For instance, the cutting and debarking manually time of one 
DOI: 10.14807/ijmp.v11i5.1292

hectare of eucalyptus is almost 25 to $30 \mathrm{~m}^{3}$ per hour, in an 8-hour journey, you can get between 200 and $250 \mathrm{~m}^{3 ”}$ (ALMEIDA, 2019).

The total workers to cutting one eucalyptus hectare are 13 to 15 in an 8-hour journey per day, and the total time is from 01 to 02 days (ALMEIDA, 2019), while the eucalyptus cutting and peeling time is carried out mechanically in 12 hours/hectare. In an experiment carried out by Leite et al. (2014), considering the mechanized processes it was observed that time to cutting down and cleaning carried out in the lowlands varied from 07 to 10 hours/hectare, and to the slope land the time was approximate from 7.5 to 11.5 hours, depending on the production spacing used.

\subsection{Cost, production and profitability analysis of manually eucalyptus production}

The cost of production is calculated based on the variables used, such as land characteristics (fertilization), pest control, technology used, labor, costs with inputs for production, and maintenance of the area. According to the results obtained the average total cost of production involving all variables was estimated at $\mathrm{R} \$ 5,500.00$ for the first cut, and in the second and third cut, the maintenance cost (fertilization, sprout selection, and cleaning) was estimated at R\$1,800.00, Table 3.

Despite the approximate reduction in maintenance costs of $34 \%$ over the second and third cycles, is observed an average productivity drop of eucalyptus between 17 and 33\%. The main reason for the productivity drops in the production is due to industry not to stimulate the continuation of eucalyptus production in the second and third cycles. And a mechanism is strategically inserted to reduce the production cost of the first cycle.

Table 3: Eucalyptus cost and productivity per hectare (manually cut)

\begin{tabular}{lccc}
\hline Factors & \multicolumn{3}{c}{ Production cycles } \\
& $\mathbf{1}^{\mathbf{0}}$ & $\mathbf{2}^{\mathbf{0}}$ & $\mathbf{3}^{\mathbf{0}}$ \\
Total cost per hectare (R\$) & 5.500 & 1.800 & 1.800 \\
Average cost per plant (R\$) & 3,30 & 1,08 & 1,08 \\
Number of trees & 1.667 & 1667 & 1667 \\
Average production time (years) & 6,5 & 6,5 & 6,5 \\
Eucalyptus (altura média do corte da tora, m) & 6 & 6 & 6 \\
Eucalyptus (average diameter standardized by the industry & 20 & 18 & 16 \\
without bark, $\mathrm{cm})$ & & & \\
Wood volume (m $\mathrm{m}^{3}$ ) & 0,18 & 0,15 & 0,12 \\
Average productivity without bark (m) & 300 & 250 & 200 \\
Productivity diference, $1^{\mathbf{0}}$ cycle (\%) & - & $17 \%$ & $33 \%$ \\
Productivity diference, $2^{\mathbf{0}}$ cycle (\%) & - & - & $20 \%$ \\
\hline
\end{tabular}

Source: Authors (2019)

From the eucalyptus test per hectare and the average price of eucalyptus of $\mathrm{R} \$ 82.00 / \mathrm{m}^{3}$ informed by the producer (CIF condition, cost, insurance, and transportation embedded in the 
DOI: 10.14807/ijmp.v11i5.1292

value of the goods), it is possible to calculate the producer's revenue and profit, as well as estimate land profitability, Table 4. Based on the minimum freight price, it was found that the freight value corresponds to approximately $18.5 \%$ of the value of the goods. This result corroborates the result presented by Machado, Gurgel, and Gameiro (2015), which presented an average transport cost of $21 \%$ for the state of São Paulo, and the approximate cost of the cutting, loading and transportation process was 34.5\%.

Table 4: Eucalyptus production profitability per production cycle (ha), CIF condition

Average price of eucalyptus: $\mathrm{R} \$ 82,00 / \mathrm{m}^{3}$

Average revenues (R\$, without bark)

Average production cost/ha (R\$)

\begin{tabular}{ccc}
\multicolumn{3}{c}{ Production cycle (manually) } \\
\hline $\mathbf{1}^{\mathbf{o}}$ & $\mathbf{2}^{\mathbf{o}}$ & $\mathbf{3}^{\mathbf{0}}$ \\
24.600 & 20.500 & 16.400 \\
5.500 & 1.800 & 1.800 \\
4.548 & 3.790 & 3.032 \\
10.048 & 5.590 & 4.832 \\
14.552 & 14.910 & 11.568 \\
$18.333,33$ & $18.333,33$ & $18.333,33$ \\
79,4 & 81,32 & 63,10 \\
12,21 & 12,51 & 9,70
\end{tabular}

Average shipping cost $(\mathrm{R} \$)^{*}$

Total cost (production and operation) (R\$)

Profit /ha (6,5 years) (R\$)

Average land price $(\mathrm{R} \$)^{+}$

Land profitability (6,5 years) (\%)

Annual land profitability (\%)

12,21

12,51

9,70

* Based on the minimum freight price, for distance up to $100 \mathrm{~km}$ (BRASIL, 2019) = R \$ 15,16/ $\mathrm{m}^{3}$; +Based on the average price of land for forestry in the Salesopólis municipality (INSTITUTO DE ECONOMIA AGRÍCOLA - IEA, 2018).
Source: Authors (2019)

Considering that the estimated total cost of the first cycle is 1.8 higher than the second cycle, it was found that the profitability in the 6.5 years is $1.92 \%$ lower in the first cycle and production. The third production cycle has dropped the land profitability of approximately $18.5 \%$ compared to the second cycle and $16.5 \%$ compared to the first cycle. Thus, it is observed that strategically the producer has a high recommendation to maintain the second cycle of production, but the third cycle would not be recommended. However, even though the third production cycle is not favorable, the profitability of the annual land is still higher than the profitability of savings established by the Central Bank and may be an alternative for producers (BANCO CENTRAL DO BRASIL, 2019).

Obviously, this paper does not aim to create economical solutions for consumers, but a notion of research on planning eucalyptus for pulp production. The academic research seeks to understand the difficulties of the current forestry activity and to point out the profitability of eucalyptus plants in comparison to the different production cycles used by producers in the Alto Tietê region. 
DOI: 10.14807/ijmp.v11i5.1292

\section{FINAL REMARKS}

Eucalyptus production in the Alto Tietê region was once a great source of income for local producers. Currently, with the drop in eucalyptus prices on the market and combined with the increase in production and transportation costs, eucalyptus production has no longer become an attractive market for producers, especially in rugged areas that have difficulties in using mechanized systems, with production carried out manually by farmers.

Producers have strategically chosen to maintain continuous cycles of eucalyptus production up to the third cut, as a way of maintaining their productive lands. However, it is observed that the maintenance of the third cycle generates a drop in land profitability varying from $16.5 \%$ to $18.5 \%$ concerning the previous cycles. This work is a presentation of the eucalyptus production condition based on the variables analyzed for the case study. Thus, before making decision, producers need to adjust their production and operation variables in the analysis performed, to verify that they obtain the same results presented in this work.

\section{REFERÊNCIAS}

ALMEIDA, J. (2019) O ciclo produtivo do eucalipto: primeiro, segundo e terceiro corte brotagem. Nota de entrevista: informação verbal. Salesópolis, 24th May, 2019.

ASSOCIAÇÃO BRASILEIRA DE PRODUTORES DE FLORESTASPLANTADAS, ABRAF. (2013) Anuário Estatístico da ABRAF: Ano base 2012. Brasília, DF: ABRAF. Available: <www.abraflor.org.br>. Access: 16th May, 2019.

BANCO CENTRAL DO BRASIL. (2019) Remuneração dos Depósitos de Poupança. Available: <https://www.bcb.gov.br/estatisticas/remuneradepositospoupanca>. Access: 08th July, 2019.

BRASIL. (2019) Resolução n. 5.842, de 23 de abril de 2019. Tabela de Preços Mínimos da Agência Nacional de Transportes Terrestres.

Available: <http://www.in.gov.br/en/web/dou/-/resolu\%C3\%A7\%C3\%A3o-n\%C2\%BA5.842-de-23-de-abril-de-2019-84797092>. Access: 08th July, 2019.

CENTRO DE PESQUISAS ECONÔMICAS, CEPEA. (2017) Os mercados de produtos florestais no Brasil. Available: https://www.cepea.esalq.usp.br/br/opiniao-cepea/osmercados-de-produtos-florestais-no-brasil.aspx\&gt. Access: 05th May, 2019.

COOPERATIVA AGRÍCOLA MISTA DE ALTO TIETÊ, CAMAT. (2019) Quem somos. Available: http://www.camat.com.br/_Access: 07th July, 2019.

FILHO, R. L. (2014) Rentabilidade da produção de eucalipto no Brasil. Available: https://www.scotconsultoria.com.br>notícias >artigos>rentabilidade-da-produção-deeucalipito-no-brasil. Access: 3rd August, 2019.

HADDAD, R. V. (2016) Campo Grande tem maior área plantada com eucalipto do centro-oeste, diz IBGE. Available: https://campograndenews.com.br>economia>ms-temmaior-área-plantada-com-eucalipto-do-centro-oeste-diz-ibge. Access: 07th September, 2019. 
DOI: 10.14807/ijmp.v11i5.1292

INSTITUTO BRASILEIRO DE GEOGRAFIA E ESTATÍSTICA, IBGE (2016). Produção da extração vegetal e da silvicultura (PEVS) 2015: $O$ valor da extração vegetal e silvicultura alcançam $\mathbf{R} \$ \mathbf{1 8 , 4}$ bilhões em 2015. Available:

https://agenciadenotícias.ibge.gov.br>2013-agencia-de-noticias>releases. Access: 16th September, 2019.

INSTITUTO BRASILEIRO DE GEOGRAFIA E ESTATÍSTICA, IBGE. (2017a) Cidades: Alto Tietê 2017. Available:<https://cidades.ibge.gov.br/brasil/sp/salesopolis/pesquisa> . Access: 14th July, 2019.

INSTITUTO BRASILEIRO DE GEOGRAFIA E ESTATÍSTICA, IBGE. (2017b) Cidades: Alto Tietê, 2005 a 2017.

Available: $<$ https://cidades.ibge.gov.br/brasil/sp/salesopolis/pesquisa/16/12705?ano=2005>.

Access: 14th July, 2019.

INSTITUTO DE ECONOMIA AGRÍCOLA. (2018) Valor da terra nua: silvicultura ou pastagem natural (terra para reflorestamento): São Paulo.

Available: $<$ http://ciagri.iea.sp.gov.br/nia1/precor_SEFAZ.aspx?cod_tipo=1\&amp;cod_is=8>. Access: 14th July, 2019.

KAKAZU, A.; ARIMATÉIA, D.; SHIVARD, F. (2013) Polissacarídeos. Available: $<$ https://edisciplinas.usp.br>. Access: 7th August, 2019.

KLOCK, U.; ANDRADE, A. S.; HERnANDEZ, J. A. (2013) Polpa e Papel. Available: www.madera.ufpr.br/disciplinasklock/polpaepapel/manualpolpa2013. Access: 7th August, 2019.

LEITE, E. S.; MINETTE, L. J.; FERNANDES, H. C.; SOUZA, A. P.; AMARAL, E. J.; LACERDA, E. G. Desempenho do harvester na colheita de eucalipto em diferentes espaçamentos de declividades. Revista Árvore, Viçosa, MG, v.38,n.1, 2014.

MACHADO, L. R.; GURGEL, A. C.; GAMEIRO, A. H. (2015) Dimensionamento e análise financeira de sistema de corte, carregamento e transporte de eucalipto. Empreendedorismo, Gestão e Negócios, v. 4, n. 4, p. 212-237.

MORAES, G. (2010) A produção de eucalipto no Brasil: Benefícios para o Meio Ambiente. Available: https://administradores.com.br>artigos. Access: 9th August, 2019.

NISHIYAMA, Y.; LANGAN, P.; CHANZY, H. (2002) Crystal Structure and HydrogenBonding System in Cellulose I $\beta$ from Synchrotron X-ray and Neutron Fiber Diffraction. Journal of the America Chemical Society, v.124, p. 31.

REVISTA AGROANALYSIS. (2014) Rentabilidade da produção de eucalipto no Brasil. 2014. Available: www.agroanalysis.com.br/eucalipto. Access: 9th August, 2019.

TURRA, T. A. (2011) Madeira de eucalipto para fins energéticos. Available: https://acervodigital.ufpr>bitstream>handle. Access: 2nd August, 2019.

VITTI, A. M. S.; BRITO; J. O. (1999) Avaliação do rendimento e do teor de citronelaldo óleo essencial de procedência e raças locais de Eucalyptus citriodora. Scientia Florestalis, v. 56, p. 145-154. 